\title{
Both Normal Memory Counts and Decreased Naive Cells Favor Intrinsic Defect Over Early Senescence of Down Syndrome T Lymphocytes
}

\author{
MAAIKE A. A. KUSTERS, EUGENIE F. A. GEMEN, RUUD H. J. VERSTEGEN, PETER C. WEVER, \\ AND ESTHER DE VRIES
}

\author{
Departments of Pediatrics [M.A.A.K., R.H.J.V., E.V.], Clinical Chemistry and Hematology [E.F.A.G.], and Medical Microbiology and \\ Infection Control [P.C.W.], Jeroen Bosch Hospital, 's-Hertogenbosch, 5200 ME, The Netherlands
}

\begin{abstract}
Because of their increased malignancies, autoimmune diseases, and infections, patients with Down syndrome (DS) show features of immunodeficiency. The DS thymus and T lymphocyte subsets have indeed proven to be different, and this has been interpreted as precocious aging. Our study on T lymphocyte subpopulations in DS shows that the normal expansion of naive helper $\left(\mathrm{CD} 4{ }^{+} \mathrm{CD}_{45 \mathrm{RA}^{+}}\right)$and cytotoxic $\left(\mathrm{CD}^{+} \mathrm{CD} 45 \mathrm{RA}^{+} \mathrm{CD} 27^{+}\right) \mathrm{T}$ lymphocytes is lacking in the first years of life; this is more logically explainable with an intrinsic $\mathrm{T}$ lymphocyte defect. Furthermore, memory cell numbers are not different from age-matched controls (AMC), which does not support the hypothesis of precocious aging. Although the absolute numbers of $\mathrm{T}$ lymphocyte subpopulations approach AMC levels toward adulthood, the persistent clinical problems suggest that these cells may not function optimally. However, the clinical picture does not fit severe $\mathrm{T}$ lymphocyte deficiency. The latter concept is also supported by our finding that cytomegalovirus (CMV)-seropositive DS children show similar numbers of terminally differentiated cytotoxic T lymphocytes when compared with healthy children, not increased numbers as are seen in immunocompromised hosts. (Pediatr Res 67: 557-562, 2010)
\end{abstract}

$\mathrm{D}$ own syndrome (DS) is associated with a high frequency of hematological malignancies (1-4), autoimmune diseases like celiac disease and hypothyroidism (5-7), as well as recurrent, mainly respiratory, infections $(2,8)$. This fits with immunodeficiency. Indeed, the thymus in DS children is smaller and abnormal (9-13), and blood T lymphocyte subpopulations differ from healthy controls (14-16). This has been interpreted as precocious aging of the immune system due to the lower relative number of $\mathrm{CD} 4{ }^{+} \mathrm{CD} 45 \mathrm{RA}^{+}$naive $\mathrm{T}$ lymphocytes $(17,18)$ and lower $\mathrm{T}$ cell-receptor excision circle counts $(19,20)$ in DS children. However, we recently showed (21) that the vast expansion of T lymphocytes in the first years of life is abrogated, favoring an intrinsic defect. We studied T lymphocyte subpopulations in DS children compared with

Received June 22, 2009; accepted January 4, 2010.

Correspondence: Esther de Vries, M.D., Ph.D., Department of Pediatrics, Jeroen Bosch Hospital (loc GZG), PO Box 90153, 5200 ME 's-Hertogenbosch, The Netherlands; e-mail: esid@estherdevries.nl; e.d.vries@jbz.nl

Supported by the JBZ Research Fund and the Irene Foundation. age-matched controls (AMC) to analyze whether the results support this alternative theory.

T lymphocyte differentiation and expansion are influenced by encountered viral infections. Especially, the expansion of CD45RA ${ }^{+} \mathrm{CD} 27^{-}$terminally differentiated cytotoxic $\mathrm{T}$ lymphocytes $(\mathrm{Tc})$, which is described as unique for cytomegalovirus (CMV) infection. The individual set point is defined by the degree of immunocompetence during the primary CMV contact: immunodeficient children show higher median absolute numbers of terminally differentiated Tc (22). To further assess the degree of immuno(in)competence in DS, we related $\mathrm{T}$ lymphocyte subpopulations to CMV serostatus and compared the DS children with groups from the literature with different immune status during primary CMV contact $(22,23)$.

\section{METHODS}

Study population. An extra $3 \mathrm{~mL}$ of EDTA blood and $7 \mathrm{~mL}$ of blood without additive was drawn from 95 noninstitutionalized DS children (49 males; mean age, 7 y; range, 1-20) visiting the Jeroen Bosch Hospital, 's-Hertogenbosch, or the Rijnstate Hospital, Arnhem, The Netherlands, during routine follow-up of thyroid function after parental informed consent. All children were otherwise healthy at the time of sampling. Leftover EDTA blood from 33 healthy AMC children who underwent venipuncture, for $e . g$. preoperative screening for minor surgery, was used as control. The study was approved by the local Medical Ethics Committees of all participating hospitals.

We divided the children into the same age groups that were used in a large Dutch reference study analyzing lymphocyte subpopulations (24). Absolute and relative numbers of T lymphocyte subpopulations were compared in DS and AMC (control) children. Absolute numbers of terminally differentiated Tc of CMV-seropositive (CMV+) DS children were compared with CMVseronegative $(\mathrm{CMV}-)$ DS children and with the results from the evaluation and discussion from recent literature $(22,23)$ including children with human immunodeficiency virus (HIV) infection, children using immunosuppressive therapy, and children who were otherwise healthy at the time of primary CMV contact.

Immunophenotyping. Three-color flow cytometric immunophenotyping was performed to determine T lymphocyte subpopulations in both DS and AMC using the lysed whole-blood method. FITC-, phycoerythrin (PE)-, and PE-cyanin 5 (PE-Cy5)-conjugated MAb were used with the following antigen specificity: CD3 (PE-Cy5; Immunotech, Marseille, France), CD3/CD4 (FITC/ PE; IQ Products, Groningen, The Netherlands), CD8 (PE-Cy5; Immunotech), CD14 [PE; Becton Dickinson (BD), San Jose, CA], CD15 (FITC; IQ Products), CD16/CD56 (FITC; BD), CD19 (PE-Cy5; Immunotech), CD27 (FITC; $\mathrm{BD}), \mathrm{CD} 45$ (PE-Cy5; Immunotech), CD45RA (PE; Coulter Immunology,

\footnotetext{
Abbreviations: AMC, Age-matched control; BD, Becton Dickinson; CMV, Cytomegalovirus; DS, Down syndrome; NK, Natural killer; PE, Phycoerythrin; PE-Cy5, PE-cyanin 5; Tc, Cytotoxic T; Th, Helper T
} 
Hialeah, FL), CD45RO (FITC; Serotec DPC, Apeldoorn, The Netherlands), TCR- $\alpha \beta$ (PE-Cy $5 ; \mathrm{BD})$, and TCR- $\gamma \delta$ (PE; BD).

Aliquots were incubated for $15 \mathrm{~min}$ at room temperature with different combinations of optimally titrated conjugated MAb to determine the following lymphocyte subpopulations: $\mathrm{T}$ lymphocytes $\left(\mathrm{CD}^{+}\right)$, B lymphocytes $\left(\mathrm{CD} 19^{+}\right)$, natural killer (NK) cells $\left(\mathrm{CD} 16^{+}\right.$and/orCD56 $\left.{ }^{+} \mathrm{CD} 3^{-}\right)$, helper $\mathrm{T}$ lymphocytes (Th) $\left(\mathrm{CD}^{+} \mathrm{CD}^{+}\right), \quad \mathrm{Tc}\left(\mathrm{CD} 3^{+} \mathrm{CD} 8^{+}\right)$, naive $\mathrm{Th}$ $\left(\mathrm{CD}^{+}{ }^{+} \mathrm{CD} 4^{+} \mathrm{CD}_{45 \mathrm{RA}^{+}}\right)$, memory $\mathrm{Th}\left(\mathrm{CD}^{+}{ }^{+} \mathrm{CD} 4^{+} \mathrm{CD} 45 \mathrm{RO}^{+}\right)$, naive $\mathrm{Tc}$ $\left(\mathrm{CD}^{+} \mathrm{CD}^{+} 5 \mathrm{RA}^{+} \mathrm{CD} 27^{+}\right)$, central memory Tc $\left(\mathrm{CD} 8^{+} \mathrm{CD} 45 \mathrm{RA}^{-} \mathrm{CD} 27^{+}\right)$, effector memory $\mathrm{Tc}\left(\mathrm{CD} 8^{+} \mathrm{CD} 45 \mathrm{RA}^{-} \mathrm{CD} 27^{-}\right)$, terminally differentiated $\mathrm{Tc}$ $\left(\mathrm{CD}^{+}{ }^{+} \mathrm{CD} 45 \mathrm{RA}^{+} \mathrm{CD} 27^{-}\right), \mathrm{CD} 3^{+} \mathrm{TCR}-\alpha \beta^{+}$, and $\mathrm{CD} 3^{+} \mathrm{TCR}-\gamma \delta^{+} \mathrm{T}$ lymphocytes. Erythrocytes were lysed using FACSLysing solution (BD) according to the manufacturer's protocol. The remaining cells were washed twice with PBS with BSA and analyzed by flow cytometry after calibration with the SPHERO CaliFlow kit (Spherotech, Libertyville, IL) as recommended by the European Working Group on Clinical Cell Analysis (25). A FACScan or FACSCalibur flow cytometer (BD) was used. Absolute leukocyte counts were determined with a Sysmex SE-9500 hematology analyzer (Sysmex, Kobe, Japan). The lymphocyte gate was checked with a CD15/CD14/CD45 triple labeling and considered correct if $<5 \%$ contamination was present. B lymphocytes and NK-cells were used to check whether the $\mathrm{T}+\mathrm{B}+\mathrm{NK}$ equaled $100 \pm 5 \%$. Absolute numbers of lymphocyte subpopulations were calculated by multiplying the absolute leukocyte count $\left(\times 10^{9} / \mathrm{L}\right)$ by the relative total lymphocyte size $(\%)$ and relative size of the lymphocyte subpopulation $(\%)$.

CMV serology and PCR. Anti-CMV IgM and IgG were measured in duplo by enzyme-linked fluorescence analysis using the VIDAS test in 90 DS children (Biomerieux, Lyon, France); from 5 DS children, serum was not available. IgG avidity tests (VIDAS, Biomerieux) were performed to differentiate between recent $(<3 \mathrm{mo})$ and late CMV contact. Real-time PCR for CMV-DNA (22) was performed in $\mathrm{CMV}-\mathrm{IgG}^{+}$children to differentiate between active and latent infection.

Review of medical files. The medical files of 91/95 DS children were reviewed retrospectively; four files were unavailable. The 91 children were divided into four groups: 1) no increased infection rate, 2) increased infection rate (age at inclusion $<8 \mathrm{y}$ ), 3) increased infection rate (age at inclusion $>8 \mathrm{y}$ ), and 4) increased infection rate until, but not after the age of $8 \mathrm{y}$. In addition, the presence of celiac disease or autoimmune hypothyroidism was noted.

Statistical analysis. To compare the T lymphocyte subpopulations between DS and AMC, the Mann-Whitney U test was used $(p<0.05)$. An analysis of variance (completely randomized two-factorial design; $p<0.05$ ) was applied to the data to test the overall effects of age (2-16 y) and group (DS and AMC). Age groups with low numbers of AMC children were excluded $(<2 ;>16 \mathrm{yr})$ from this analysis. Levene's test for equality of error variances was used on all subpopulations $(p<0.05)$. Tc subpopulations of CMV-seronegative $(\mathrm{CMV}-)$ and CMV+ DS children were analyzed after $\log$ transformation by $t$ test $(p<0.05)$. All analyses were performed with SPSS 16.0 for Windows.

\section{RESULTS}

The absolute and relative numbers of the analyzed $\mathrm{CD}^{+} \mathrm{T}$ lymphocyte subpopulations, and the results of the statistical analyses are listed in Table 1 (the values for $\mathrm{CD}^{+} \mathrm{T}$ lymphocytes, $\mathrm{CD}^{+}{ }^{+} \mathrm{CD} 4^{+} \mathrm{Th}$, and $\mathrm{CD} 3{ }^{+} \mathrm{CD} 8^{+} \mathrm{Tc}$ were reported before (21)). None of the interaction effects were significant. This means that the effects of age on the various T lymphocyte subpopulations do not differ between DS children and AMC children; although $\mathrm{T}$ lymphocytes and Th lack the expansion normally seen in the first years of life (24), the overall pattern seen in time is the same in DS and AMC. Clinically, relevant data are presented in Table 2. We did not find a relation between any of the determined $\mathrm{T}$ lymphocyte subpopulations and the incidence of infections or autoimmune diseases in these DS children.

Naive and memory $\mathrm{CD3}^{+} \mathrm{CD4}^{+} \mathrm{Th}$. The absolute numbers of CD45RA ${ }^{+}$naive Th are reduced in DS children. Naive Th lack the expansion seen in AMC children during the first years of life, but the overall pattern seen in time is the same in both DS children and AMC children. Despite increased relative numbers of $\mathrm{CD} 45 \mathrm{RO}^{+}$memory Th, absolute numbers do not differ from AMC children due to the lower absolute counts of total Th in DS children. The memory Th subset does not show an age-related change in size in either DS or AMC children (Fig. 1).

Naive, central memory, effector memory, and terminally differentiated $\mathrm{CDB}^{+} \mathrm{Tc}$. Like naive Th, the absolute numbers of $\mathrm{CD} 45 \mathrm{RA}^{+} \mathrm{CD} 27^{+}$naive Tc are decreased in DS and lack the normal expansion seen in AMC during the first years of life, although the overall pattern seen in time is the same in DS and AMC. The absolute numbers of both $\mathrm{CD} 45 \mathrm{RA}^{-} \mathrm{CD} 27^{+}$ central memory and $\mathrm{CD} 45 \mathrm{RA}^{-} \mathrm{CD} 27^{-}$effector memory $\mathrm{Tc}$ are higher in DS than in AMC, but values differ widely (Levene's test: $p=0.009$ and $p=0.003$, respectively). The absolute numbers of $\mathrm{CD}_{4} 4 \mathrm{RA}^{+} \mathrm{CD} 27^{-}$terminally differentiated Tc are low in all age groups in both DS as well as AMC children. Neither in memory Th, the memory Tc subsets show an age-related change in size in DS or AMC (Fig. 2).

TCR- $\alpha \beta^{+}$and TCR- $\gamma \delta^{+} C D D 3^{+}$T lymphocytes. The absolute number of TCR- $\gamma \delta+\mathrm{T}$ lymphocytes in DS children is lower but values widely differ in AMC children (Levene's test: $p=0.000$ ). As was expected, the absolute numbers of TCR- $\alpha \beta+\mathrm{T}$ lymphocytes follow the pattern of total $\mathrm{T}$ lymphocytes.

CMV status and terminally differentiated $\mathrm{CDS}^{+} \mathrm{Tc}$. Twenty of the 90 tested DS children are CMV +, they all have a latent infection $\left(\mathrm{IgG}^{+} \mathrm{IgM}^{-} ; \mathrm{PCR}^{-}\right.$Avidity $\left.{ }^{\text {hi }}\right)$. The median absolute number of CD45RA ${ }^{+} \mathrm{CD} 27^{-}$terminally differentiated Tc in CMV + DS children is $0.079 \times 10^{9}$ cells/ $/$ (range, $0.007-0.36$ ), and $0.017 \times 10^{9}$ cells $/ \mathrm{L}$ (range, $0.0004-0.22$ ) in CMV - DS children $(p<0.001)$. In CMV + healthy children, a median absolute number of $\mathrm{CD} 45 \mathrm{RA}^{+} \mathrm{CD} 27^{-}$terminally differentiated $\mathrm{Tc}$ of $0.067 \times 10^{9}$ cells/ $\mathrm{L}$ is described (22). Higher absolute numbers are described in children with primary CMV infection during immunosuppressive therapy (median, $0.413 \times 10^{9}$ cells $\left./ \mathrm{L}\right)$ and in CMV + HIV-1 infected children (median, $0.369 \times 10^{9}$ cells/L) $(22,23)($ Fig. 3).

\section{DISCUSSION}

DS children lack the expansion of both naive Tc and naive Th normally seen in the first years of life; memory Tc and memory Th are not influenced by age in either DS or AMC children. With advancing age, numbers of memory Th, terminally differentiated Tc and TCR- $\gamma \delta+$ T lymphocytes normally increase (17). Despite earlier statements in the literature suggesting precocious ageing of T lymphocytes in DS, however, in our DS cohort, no early shift toward these T lymphocyte subsets occurred. A more likely explanation of the observed T lymphocyte subset alterations in DS children would therefore be that the decreased numbers of Tc but particularly of Th are the result of (partial) the failure of $\mathrm{T}$ lymphocyte generation, an intrinsic T lymphocyte defect, an increased apoptosis, or a combination of these.

It is interesting to speculate about this finding. Apoptosis data in DS is scarce, but Elsayed and Elsayed (26) recently described increased early apoptosis markers in DS T lymphocytes. Thymic alterations in DS are well-known $(9,10,12,13)$, 


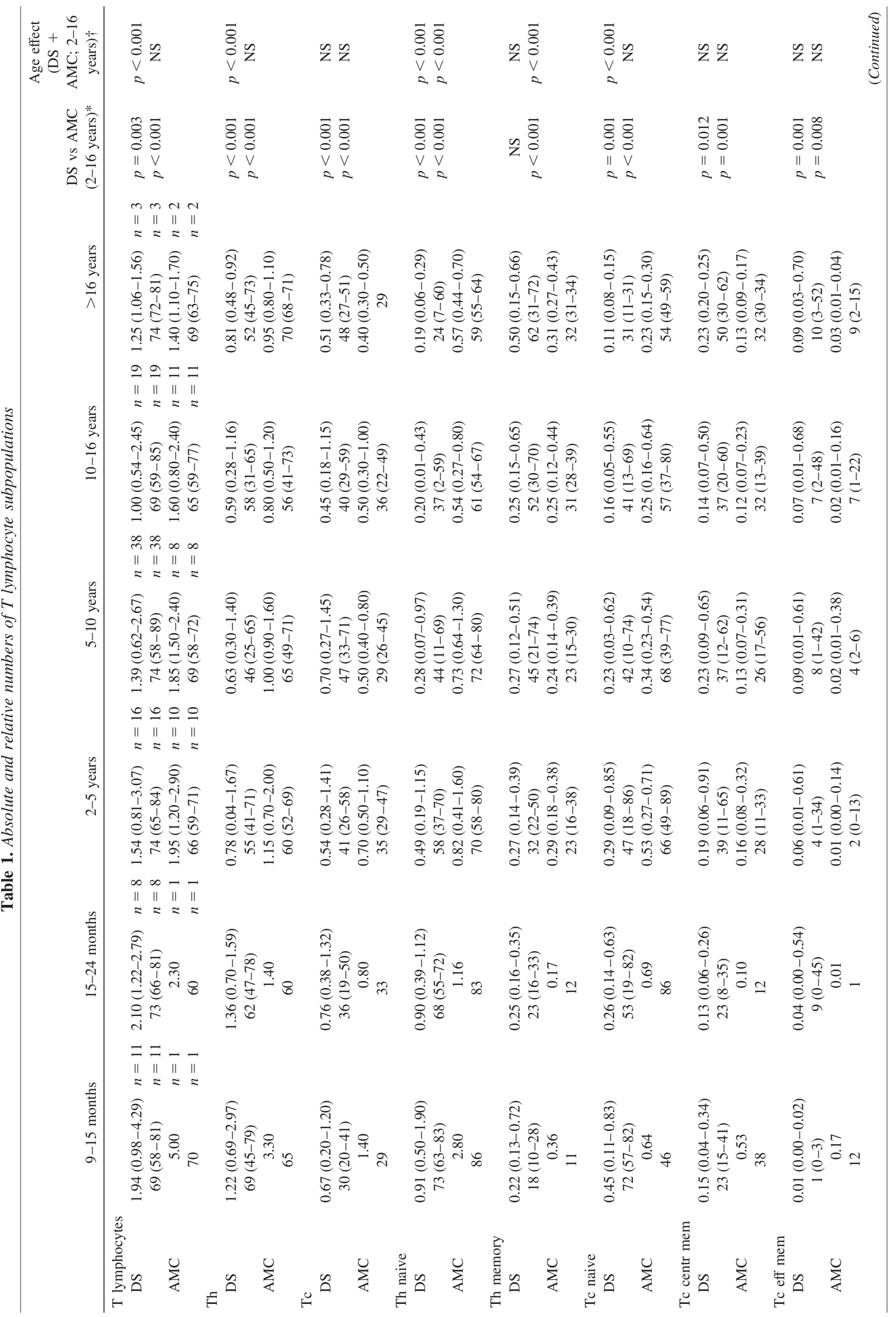


KUSTERS ET AL.

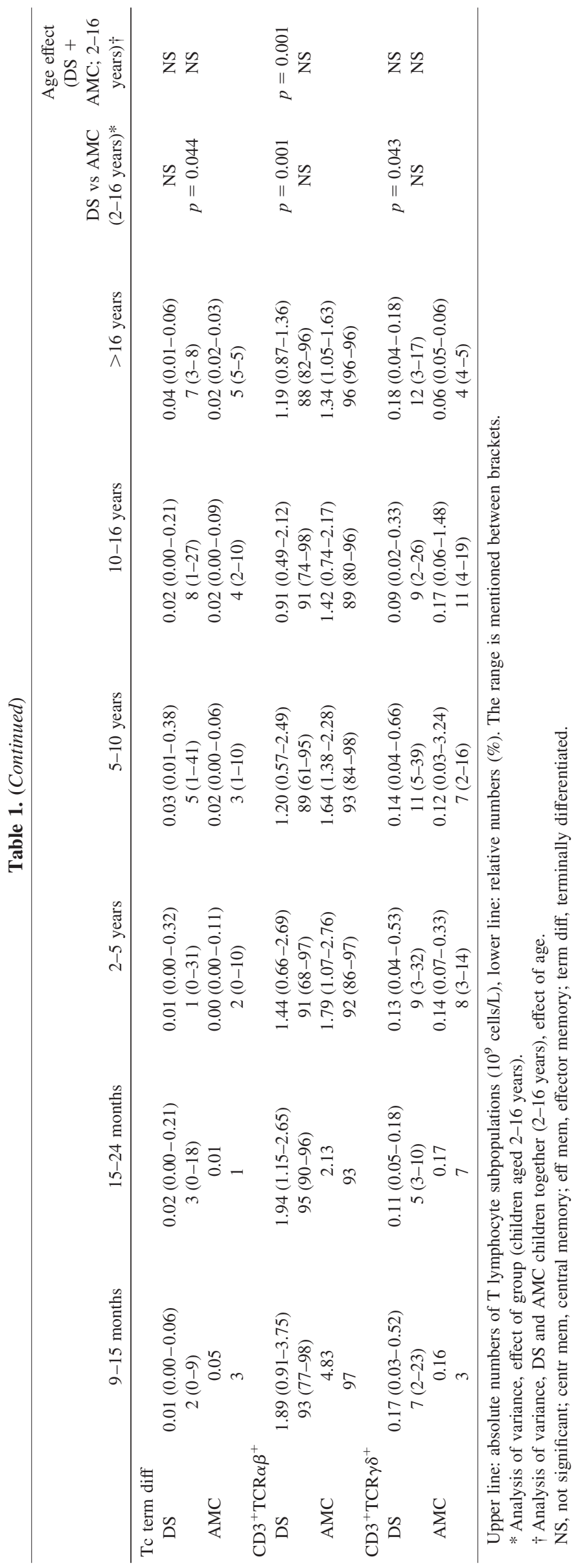


Table 2. Clinical features

\begin{tabular}{|c|c|c|c|c|c|c|c|}
\hline & $\begin{array}{l}9-15 \text { months } \\
(n=11)\end{array}$ & $\begin{array}{l}15-24 \text { months } \\
(n=4)\end{array}$ & $\begin{array}{l}2-5 \text { years } \\
(n=16)\end{array}$ & $\begin{array}{l}5-10 \text { years } \\
(n=38)\end{array}$ & $\begin{array}{l}10-16 \text { years } \\
\quad(n=19)\end{array}$ & $\begin{array}{l}>16 \text { years } \\
(n=3)\end{array}$ & $\begin{array}{c}\text { Total } \\
(n=91)\end{array}$ \\
\hline No increased infection rate (all ages) & $n=5$ & & $n=6$ & $n=5$ & $n=1$ & $n=2$ & $n=19$ \\
\hline $\begin{array}{l}\text { Increased-mainly respiratory-infection rate } \\
\quad(\text { age at inclusion }<8 \text { y) }\end{array}$ & $n=6$ & $n=4$ & $n=10$ & $n=20$ & & & $n=40$ \\
\hline $\begin{array}{l}\text { Increased-mainly respiratory-infection rate } \\
\text { until, but not after, the age of } 8 \mathrm{y}\end{array}$ & & & & $n=6$ & $n=12$ & & $n=18$ \\
\hline $\begin{array}{l}\text { Increased-mainly respiratory-infection rate } \\
\quad(\text { age at inclusion }>8 \mathrm{y})\end{array}$ & & & & $n=7$ & $n=6$ & $n=1$ & $n=14$ \\
\hline Celiac disease & $n=0$ & $n=1$ & $n=1$ & $n=2$ & $n=1$ & $n=0$ & $n=5$ \\
\hline Autoimmune hypothyroidism & $n=0$ & $n=1$ & $n=0$ & $n=1$ & $n=1$ & $n=0$ & $n=3$ \\
\hline
\end{tabular}
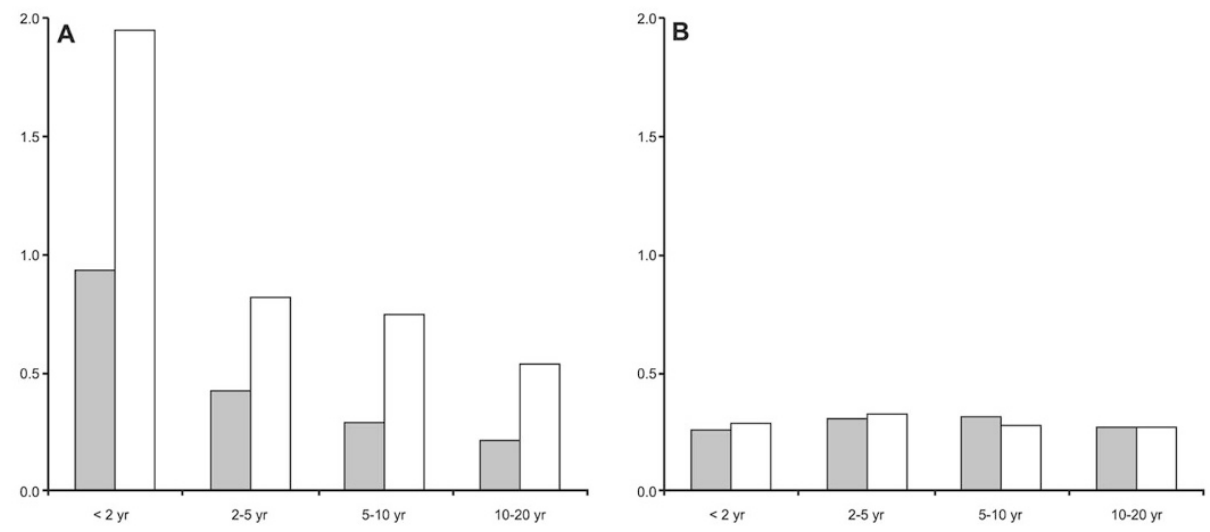

Figure 1. Median absolute numbers $\left(\times 10^{9} / \mathrm{L}\right)$ of helper $\mathrm{T}$ lymphocytes per age group. (A) Naive helper $\mathrm{T}$ lymphocytes $\left(\mathrm{CD}^{+} \mathrm{CD}^{+}{ }^{+} \mathrm{CD} 45 \mathrm{RA}^{+}\right) ;(B)$ memory helper $\mathrm{T}$ lymphocytes $\left(\mathrm{CD}^{+}{ }^{+} \mathrm{CD} 4{ }^{+} \mathrm{CD} 45 \mathrm{RO}^{+}\right)$. Gray bars, DS children; white bars, agematched reference values.

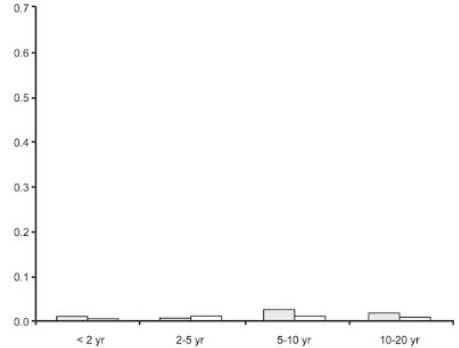

Terminally differentiated CD45RA+CD27
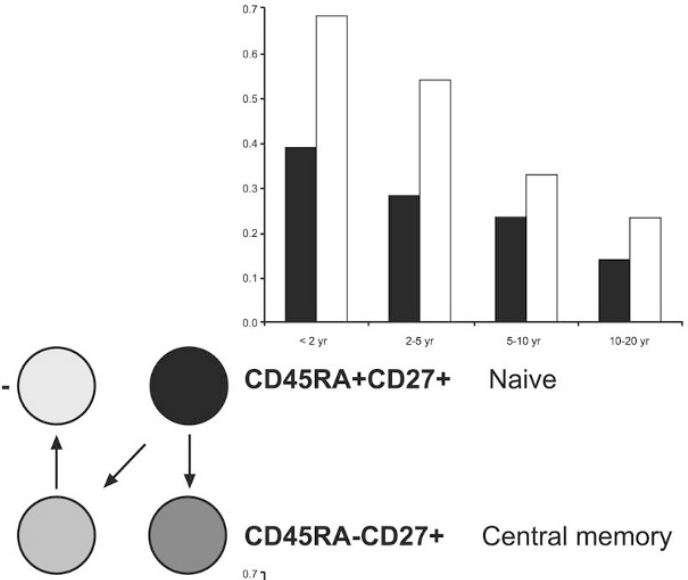

CD45RA+CD27+ Naive

Effector memory

CD45RA-CD27-

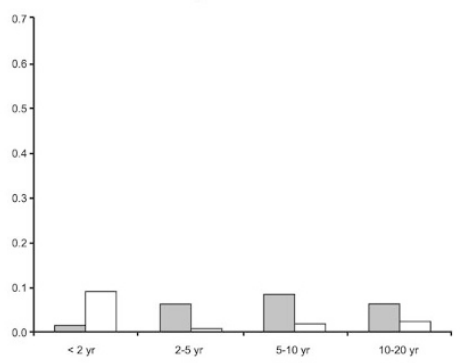

CD45RA-CD27+ Central memory

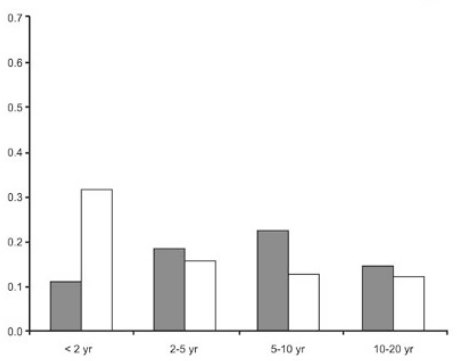

Figure 2. Median absolute numbers $\left(\times 10^{9} / \mathrm{L}\right)$ of cytotoxic T lymphocyte subpopulations per age group. gray and black bars, DS children; white bars, corresponding age-matched reference values. and are already described in DS fetuses (27), suggesting T lymphocyte generation is impaired by a defect in the DS thymus. This situation resembles children with DiGeorge syndrome who have a smaller or absent thymus; they demonstrate decreased (total) Th and Tc subsets as well $(28,29)$. In DiGeorge syndrome, however, most cases appear to gradually reach $\mathrm{T}$ lymphocyte levels of healthy adults over time. In comparison, naive Tc in our DS children reach normal levels during adolescence, but naive Th remain decreased. It is still uncertain whether these cells function normally, having shown such a profound lack of the antigen-driven expansion in earlier years. In vitro tests of T lymphocyte function support this (30). 


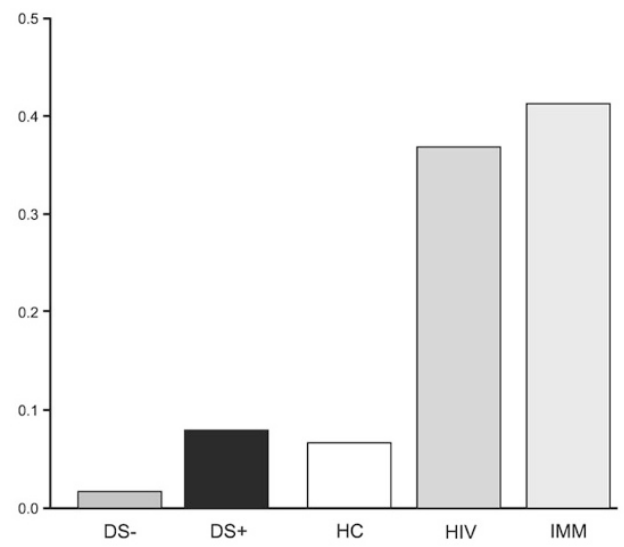

Figure 3. Median absolute numbers $\left(\times 10^{9} / \mathrm{L}\right)$ of terminally differentiated cytotoxic T lymphocytes per group. HC, healthy children and IMM, receiving immunosuppressive medication during primary cytomegalovirus infection.

Clinically speaking, DS children do not show signs of a profound T lymphocyte deficiency. This corresponds with our finding that CMV+ DS children show absolute numbers of terminally differentiated Tc comparable to healthy children, not to immunocompromised, e.g. HIV + , children.

In conclusion, the observed T lymphocyte alterations in DS are more likely caused by an intrinsic defect than by early senescence of the immune system. In the future, functional studies of $\mathrm{T}$ lymphocytes may help to differentiate between a defect primarily originating in the thymus (as in DiGeorge syndrome), a defect in the $\mathrm{T}$ lymphocytes themselves, increased apoptosis, or a combination of these options.

Acknowledgments. We thank patients and parents for their cooperation with the study and Mr. Jeroen Ooms for preparing the figures.

\section{REFERENCES}

1. Fabia J, Droletter M 1970 Malformations and leukemia in children with Down syndrome. Pediatrics 45:60-70

2. Goldacre MJ, Wotton CJ, Seagroatt V, Yeates D 2004 Cancers and immune related diseases associated with Down syndrome: a record linkage study. Arch Dis Child 89:1014-1017

3. Fraumeni JF, Manning MD, Mitus WJ 1971 Acute childhood leukemia: epidemiological study by cell type in 1263 cases at the Children's Cancer Research Foundation in Boston. J Natl Cancer Inst 46:461-470

4. Miller RW 1970 Neoplasia and Down's syndrome. Ann NY Acad Sci 171:637-644

5. Storm W 1990 Prevalence and diagnostic significance of gliadin antibodies in children with Down syndrome. Eur J Pediatr 149:833-834

6. Karlsson B, Gustafsson J, Hedov G, Ivarsson SA, Anneren G 1998 Thyroid dysfunction in Down's syndrome: relation to age and thyroid autoimmunity. Arch Dis Child 79:242-245

7. Sanchez-Albisua I, Storm W, Wascher I, Stern M 2002 How frequent is coeliac disease in Down syndrome? Eur J Pediatr 161:683-684

8. Garrison MM, Jeffries H, Christakis DA 2005 Risk of death for children with Down syndrome and sepsis. J Pediatr 147:748-752
9. Levin S, Schlesinger M, Handzel ZT 1979 Thymic deficiency in Down's syndrome. Pediatrics 63:80-83

10. Murphy M, Lempert MJ, Epstein LB 1990 Decreased level of T cell receptor expression by Down syndrome (trisomy 21) thymocytes. Am J Med Genet Suppl 7:234-237

11. Murphy M, Epstein LB 1990 Down syndrome (trisomy 21) thymuses have a decreased proportion of cells expressing high levels of TCR alpha, beta and CD3. Clin Immunol Immunopathol 55:453-467

12. Larocca LM, Lauriola L, Ranelletti FO, Piantelli M, Maggiano N, Ricci R, Capelli A 1990 Morphological and immunohistochemical study of Down syndrome thymus. Am J Med Genet Suppl 7:225-230

13. Musiani P, Valitutti S, Castellino F, Larocca LM, Maggiano N, Piantelli M 1990 Intrathymic deficient expansion of T cell precursors in Down syndrome. Am J Med Genet Suppl 7:219-224

14. Kusters MA, Verstegen RH, Gemen EF, de Vries E 2009 Intrinsic defect of the immune system in children with Down syndrome: a review. Clin Exp Immunol 156:189-193

15. Burgio GR, Lanzavecchia A, Maccario R, Vitiello A, Plebani A, Ugazio AG 1978 Immunodeficiency in Down's syndrome: T-lymphocyte subset imbalance in trisomic children. Clin Exp Immunol 33:298-301

16. Cossarizza A, Monti D, Montagnani G, Ortolani C, Masi M, Zannotti M, Franceschi C 1990 Precocious aging of the immune system in Down syndrome: alteration of B lymphocytes, T lymphocyte subsets, and cells with natural killer markers. Am J Med Genet Suppl 7:213-218

17. Cossarizza A, Ortolaini C, Paganelli R, Barbieri D, Monti D, Sansoni P, Fagiolo U, Castellani G, Bersani F, Londei M, Franceschi C 1996 CD45 isoform expression on $\mathrm{CD}^{+}$and $\mathrm{CD}^{+}{ }^{+} \mathrm{T}$ cells throughout life, from newborns to centenarians: implications for T cell memory. Mech Ageing Dev 86:173-195

18. Murphy M, Epstein LB 1992 Down syndrome peripheral blood contains phenotypically mature $\mathrm{CD}^{+} \mathrm{TCR}$ alpha, beta ${ }^{+}$cells but abnormal proportions of TCR alpha, beta $^{+}$, TCR gamma, delta ${ }^{+}$and $\mathrm{CD} 4{ }^{+} \mathrm{CD} 45 \mathrm{RA}^{+}$cells: evidence for an inefficient release of mature T cells by DS thymus. Clin Immunol Immunopathol 62:245-251

19. Prada N, Nasi M, Troiano L, Roat E, Pinti M, Nemes E, Lugli E, Ferraresi R, Ciacci L, Bertoni D, Biagioni O, Gibertoni M, Cornia C, Meschiari L, Gramazio E, Mariotti M, Consolo U, Balli F, Cossarizza A 2005 Direct analysis of thymic function in children with Down's syndrome. Immun Ageing 2:4

20. Roat E, Prada N, Lugli E, Nasi M, Ferraresi R, Troiano L, Giovenzana C, Pinti M, Biagioni O, Mariotti M, Di Lorio A, Consolo U, Balli F, Cossarizza A 2008 Homeostatic cytokines and expansion of regulatory $\mathrm{T}$ cells accompany thymic impairment in children with Down syndrome. Rejuvenation Res 11:573-583

21. De Hingh YC, van der Vossen PW, Gemen EF, Mulder AB, Hop WC, Brus F, de Vries E 2005 Intrinsic abnormalities of lymphocyte counts in children with Down syndrome. J Pediatr 147:744-747

22. Kuijpers TW, Vossen MT, Gent M, Davin JC, Roos MT, Wertheim-van Dillen PM, Weel JF, Baars PA, van Lier RA 2003 Frequencies of circulating cytolytic, $\mathrm{CD}_{5} \mathrm{RA}^{+} \mathrm{CD}^{2} 7^{-}, \mathrm{CD}^{+}{ }^{+} \mathrm{T}$ lymphocytes depend on infection with CMV. J Immunol 170:4342-4348

23. Bekker V, Bronke C, Scherpbier HJ, Weel JF, Jurriaans S, Wertheim-van Dillen PM, van Leth F, Lange JM, Tesselaar K, van Baarle D, Kuijpers TW 2005 Cytomegalovirus rather than HIV triggers the outgrowth of effector $\mathrm{CD} 8^{+} \mathrm{CD} 45 \mathrm{RA}^{+} \mathrm{CD} 27^{-}$ $\mathrm{T}$ cells in HIV+-infected children. AIDS 19:1025-1034

24. Comans-Bitter WM, de Groot R, van den Beemd R, Neijens HJ, Hop WC, Groeneveld K, Hooijkaas H, van Dongen JJ 1997 Immunophenotyping of blood lymphocytes in childhood. J Pediatr 130:388-393

25. Kraan J, Gratama JW, Keeney M, D'Hautcourt JL 2003 Setting up and calibration of a flow cytometer for multicolor immunophenotyping. J Biol Regul Homeost Agents 17:223-233

26. Elsayed SM, Elsayed GM 2009 Phenotype of apoptotic lymphocytes in children with Down syndrome. Immun Ageing 6:2

27. Sustrova M, Sarikova V 1997 Down's syndrome-effect of increased gene expression in chromosome 21 on the function of the immune and nervous system [in Slovak]. Bratisl Lek Listy 98:221-228

28. Chinen J, Rosenblatt HM, O'Brian Smith E, Shearer WT, Noroski LM 2003 Long-term assessment of T-cell populations in DiGeorge syndrome. J Allergy Clin Immunol 111:573-579

29. Jawad AF, McDonald-McGinn DM, Zackai E, Sullivan KE 2001 Immunologic features of chromosome 22q11.2 deletion syndrome (DiGeorge syndrome/ velocardiofacial syndrome). J Pediatr 139:715-723

30. Burgio GR, Ugazio AG, Nespoli L, Maccario AF, Botelli AM, Pasquali F 1975 Derangements of immunoglobulin levels, phytohemagglutinin responsiveness and $\mathrm{T}$ and B cell markers in Down's syndrome at different ages. Eur J Immunol 5:600-603 